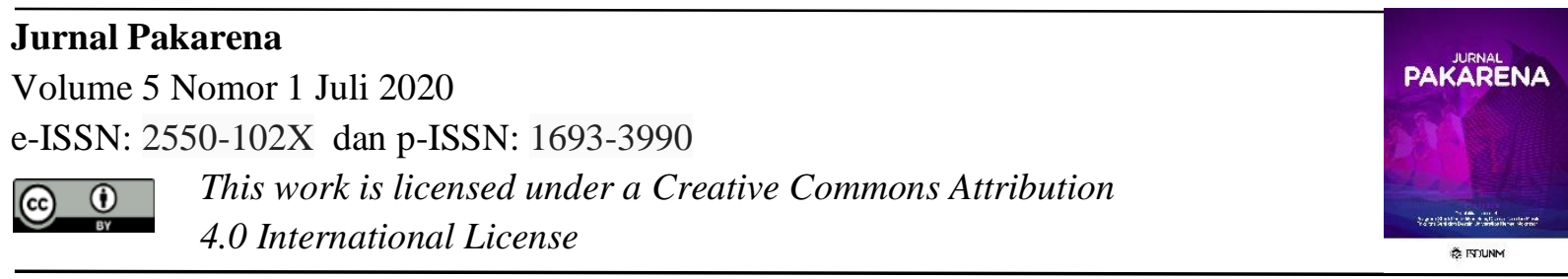

\title{
ANALISIS DAYA DUKUNG RUANG KULIAH DAN RUANG LABORATORIUM/STUDIO PROGRAM STUDI PENDIDIKAN SENI RUPA PADA FAKULTAS SENI DAN DESAIN UNIVERSITAS NEGERI MAKASSAR DITINJAU DARI ASPEK DESAINNYA
}

\section{Agussalim Djirong \& Sukarman B}

Keywords :

Kata Kunci; Keefektifan;

Tata Ruang; Laboratorium.

\section{Corespondensi Author}

Desain Komunikasi Visual

Fakultas Seni dan Desain

Universitas Negeri Makassar

Email:

agussalim.djirong@unm.ac.id

sukarman.b@unm.ac.id

story Artikel

Received: 23-Januari-2020;

Reviewed: 22-Juni-2020;

Revised: 23-Juni-2020;

Accepted: 24-Juni-2020;

Published: 24-Juni-2020.

\begin{abstract}
ABSTRAK
Penelitian ini berjudul "Keefektifan Tata Ruang Kuliah dan Ruang Laboratorium/Studio Program Studi Pendidikan Seni Rupa pada Fakultas Seni dan Desain Universitas Negeri Makassar Ditinjau dari Aspek Desainnya”. Penelitian ini dilatari oleh pemikiran bahwa beberapa ruang pada kampus Fakultas Seni dan Desain (FSD) Universitas Negeri Makassar, telah mengalami perubahan tataan yang diduga tanpa didahului dengan kajian yang mendalam terhadap berbagai aspek yang mempengaruhi kenyamanan penggunaan ruang tersebut serta dengan pengerjaan yang tidak maksimal karena berbagai keterbatasan. Akibatnya, tata ruang yang dilakukan juga kurang efektif dalam upaya memenuhi kebutuhan kenyamanan penggunaan ruang tersebut. Alasan ini mendasari sehingga dipandang perlu penelitian yang dapat mengungkap secara ilmiah keadaan yang sesungguhnya. Masalah penelitian yang akan menjadi fokus penelitian ini, yakni "bagaimanakah keefektifan tata ruang kuliah dan ruang laboratorium/studio Program Studi Pendidikan Seni Rupa pada kampus Fakultas Seni dan Desain Universitas ditinjau dari aspek desainnya". Tujuannya adalah mengetahui secara akurat serta menjelaskan keefektifan tata ruang dalam kampus Fakultas Seni dan Desain UNM ditinjau dari aspek desainnya. Tujuan berikutnya apabila tata ruang tersebut ternyata kurang efektif adalah mengetahui dan mengungkapkan unsur-unsur dari tata ruang tersebut yang dipandang kurang mendukung. Manfaatnya antara lain adalah memberikan informasi mengenai keefektifan tata ruang dalam (interior) yang dilakukan pada kampus FSD-UNM selama ini, sekaligus menjadi masukan kepada pihak berwenang dalam melakukan penataan ruang di masa datang. Metode yang ditempuh untuk memperoleh data yang dibutuhkan adalah survei dan dokumentasi. Data yang diperoleh selanjutnya dianalisis secara kualitatif berasarkan teori-teori desain (interior) yang lazim digunakan. Kesimpulan, beberapa unsur pendukung suasana ruang tidak secara efektif mendukung terwujudnya kenyamanan penggunaan dan pencitraan dan estetika ruang. Berdasarkan kesimpulan tersebut disarankan melakukan redesain atau penataan ulang terhadap ruangan tersebut untuk meningkatkan efektivitasnya.
\end{abstract}

\footnotetext{
ABSTRACT

The study was entitled "The Effectiveness of Lecture Spaces and Laboratory / Studio Spaces in the Study Program of Fine Arts Education at the Faculty of Art and Design in Makassar State University Judging from its Design Aspects". This research is motivated by the thought that some of the spaces on the campus of the Faculty of Art and Design (FSD) Makassar State University, have undergone a change in order that is suspected without being preceded by an in-depth study of various aspects that affect the comfort of the use of the space and with work that is not optimal due to various limitations. As a result, the spatial plan carried out was also less effective in an effort to meet the
} 
Agussalim Djirong \& Sukarman B, Analisis Daya Dukung Ruang Kuliah Dan Ruang Laboratorium/Studio Program Studi Pendidikan Seni Rupa Pada Fakultas Seni Dan Desain Universitas Negeri Makassar Ditinjau Dari

Aspek Desainnya.

comfort needs of the use of the space. This reason is so underlying that it is deemed necessary research that can uncover scientifically the real situation. The research problem that will be the focus of this research, namely "how is the effectiveness of the lecture room and laboratory/studio space of the Fine Arts Education Study Program on the campus of the Faculty of Art and Design University in terms of design aspects". The aim is to know accurately and explain the effectiveness of spatial planning in the campus of the Faculty of Art and Design UNM in terms of design aspects. The next goal if the spatial planning turns out to be less effective is to know and express the elements of the spatial plan which are seen as less supportive. The benefits include providing information on the effectiveness of interior layout carried out on the FSD-UNM campus all this time, as well as providing input to the authorities in conducting spatial planning in the future. The method used to obtain the data needed is a survey and documentation. The data obtained are then analyzed qualitatively based on design theories (interior) that are commonly used. In conclusion, some supporting elements of spatial atmosphere do not effectively support the realization of comfort in the use and imaging and aesthetics of space. Based on these conclusions it is recommended to redesign or restructure the room to increase its effectiveness.

\section{PENDAHULUAN}

Ruang merupakan sesuatu yang sangat dekat dengan manusia karena dalam kehidupan manusia selalu berada di suatu ruang dan selalu berhubungan dengan ruang. Manusia memerlukan ruang sebagai wadah untuk melakukan berbagai kegiatannya. Manusia senantiasa berinteraksi, berintegrasi, bahkan menyatukan dirinya dengan ruang dalam konteks fisik maupun mental, baik hal itu disadari maupun tidak. Suatu ruang bagi manusia bisa menjadi sesuatu yang menyenangkan dan menenangkan, sebaliknya dapat pula menjadi sesuatu yang menggerahkan dan menggelisahkan. Bagi orang yang menyadari hubungan suatu ruang dengan dirinya biasanya berusaha menyiasati ruang tersebut agar menjadi sesuatu yang menyenangkan bahkan mungkin bermakna bagi dirinya. Singkatnya, ruang merupakan kebutuhan mendasar yang tidak terpisahkan dengan manusia, dan oleh karena itu setiap orang menginginkan penataan ruang hingga menjadi sesuatu yang menyenangkan serta mendukung pencapaian maksimal kegiatan yang dilakukan pada ruang tersebut.

Pada kampus FSD (Fakultas Seni dan Desain) UNM (Universitas Negeri Makassar), beberapa ruang dalam telah mengalami perubahan tataan, bahkan ada yang mengalami beberapa kali.
Perubahan tata ruang dalam itu acap kali dilakukan sejak sebelum dan setelah FSD berdiri pada tahun 2007 disebabkan oleh adanya keinginan untuk menyesuaikan dengan kebutuhan yang berkembang pada saat itu. Namun, kerap kali perubahan tata ruang dalam itu berlangsung tanpa kajian yang mendalam terhadap berbagai aspek yang mempengaruhi keefektifan penggunaan ruang tersebut serta dengan pengerjaan yang tidak maksimal karena berbagai keterbatasan. Perubahan yang dilakukan dengan penuh keterbatasan itu sangat memungkinkan berbagai komponen penentu keefektifan terhadap hasil tataan ruang tidak terperhitungkan dengan baik. Akibatnya, tata ruang dalam yang dilakukan juga sangat mungkin kurang efektif dalam upaya memenuhi keefektifan penggunaan ruang tersebut. Salah satu indikator adanya kemungkinan kekurangefektifan tersebut adalah adanya keluhan yang biasa diungkapkan secara spontan oleh pengguna, baik dari kalangan mahasiswa maupun dari kalangan dosen, pada saat menggunakan ruang dalam yang dimaksud.

Berdasarkan adanya keluhan pengguna terhadap tata ruang dalam yang selama ini berlangsung pada kampus FSD tersebut sehingga dipandang perlu melakukan penelitian yang dapat mengungkap secara ilmiah keadaan itu. Atas 
pertimbangan itu sehingga penelitian yang bermaksud mengungkap keefektifan tata ruang dalam pada kampus FSD-UNM ini berdasarkan teori desain dilakukan, dengan fokus kajian terhadap ruang kuliah dan ruang lab/studio Program Studi Pendidikan Seni Rupa.

Berdasarkan latar belakang masalah yang telah dikemukakan di atas, diajukan masalah penelitian yang menjadi fokus penelitian ini, yakni "bagaimanakah keefektifan tata ruang kuliah dan ruang lab/studio Program Studi Pendidikan Seni Rupa pada kampus Fakultas Seni dan Desain Universitas Negeri Makassar ditinjau dari aspek desain".

Penelitian ini dilakukan dengan tujuan utama adalah mengetahui secara akurat serta menjelaskan keefektifan tata ruang dalam kampus Fakultas Seni dan Desain UNM, terutama ditinjau dari aspek desain. Tujuan berikutnya apabila tata ruang tersebut dipandang kurang efektif adalah mengetahui dan mengungkapkan unsur-unsur dari tata ruang tersebut yang dipandang kurang mendukung.

Manfaat utama penelitian ini adalah memberikan informasi mengenai keefektifan tata ruang dalam (interior) yang telah dilakukan pada kampus FSD-UNM selama ini, sekaligus menjadi masukan kepada pihak berwenang dalam melakukan penataan ruang di masa datang. Di samping itu, hasil penelitian ini juga dapat bermanfaat sebagai informasi atau bahan rujukan dalam melakukan kajian terhadap masalah relevan, atau melakukan kajian yang sama dari sudut pandang yang lain.

\section{METODE}

Berdasarkan judul yang diajukan, ditetapkan variabel yang menjadi fokus kajian dalam peneltian ini, yakni efektifitas tata ruang ditinjau dari aspek desain, yang secara operasional didefinisikan sebagai "daya dukung" unsur pembentuk ruang dan seluruh komponen pendukungnya dalam penciptaan suana nyamanan dan ketepatgunaan ruang dalam (interior) berdasarkan kesesuaian dengan prinsip-prinsip desain dan tata ruang yang lazim digunakan.
Sasaran utama penelitian ini adalah ruang kuliah sebanyak 7 ruangan dan ruang lab/studio sebanyak 6 ruangan pada program studi Pendidikan Seni Rupa Fakultas Seni dan Desain Universitas Negeri Makassar.

Data yang dibutuhkan dalam penelitian ini berupa data visual beserta catatan yang mendeskripsikan keadaan setiap ruang yang diteliti. Data itu diperoleh dengan cara melakukan survei secara langsung pada setiap ruang dan mencatat kondisi riil tata ruang tersebut dan mendokumentasikannya melalui rekaman kamera foto dan atau kamera video.

Data yang telah diperoleh diolah dengan cara mengelompokkan data visual dan catatan survei menurut ruangnya. Selanjutnya, data yang telah diolah kemudian dianalisis secara kualitatif dengan melakukan komparasi antara kondisi riil tata ruang dengan prinsip desain tata ruang dalam (interior) yang lazim digunakan.

\section{HASIL DAN PEMBAHASAN \\ Hasil}

\section{A. Pengertian dan Prinsip Dasar Desain}

1. Pengertian Desain

"Desain" berasal dari kata design

(Inggeris) yang berarti potongan, bentuk, model, pola, konstruksi, mode, dan tujuan. Dalam bahasa Indonesia, desain diartikan kerangka bentuk atau rancangan. Di dalam perkembanganya, istilah "desain" banyak didefinisikan dari sudut pandang yang berbeda-beda, di antaranya:

- Alexander (1963), desain adalah proses pencarian komponen fisik yang tepat dari suatu struktur fisik.

- Bruce Archer, desain adalah aktivitas pemecahan masalah yang terarah.

- Gregory (1966), desain adalah upaya mempertautkan produk dengan situasi untuk memberikan kepuasan.

- J.K.Page, desain adalah lompatan yang penuh imajinasi dari kenyataan kini ke kemungkinan masa datang.

- M.E.Bevlin, desain adalah organisasi bagian-bagian ke dalam suatu keseluruhan yang harmonis. 
Agussalim Djirong \& Sukarman B, Analisis Daya Dukung Ruang Kuliah Dan Ruang Laboratorium/Studio Program Studi Pendidikan Seni Rupa Pada Fakultas Seni Dan Desain Universitas Negeri Makassar Ditinjau Dari

- Solihin, desain adalah terjemahan fisik akan aspek sosial, ekonomi dan tata hidup manusia serta merupakan cerminan budaya zamannya.

- Belvin, Marjorie Elliot, desain adalah organisasi bagian-bagian ke dalam suatu keseluruhan yang harmonis.

\section{Prinsip Dasar Desain}

Ada dua prinsip dasar desain yang di dalam uraian berikut ini disebut sebagai aspek yang patut dipertimbangkan dalam mendesain, yaitu aspek fungsi dan aspek estetik.

\section{a. Aspek Fungsi}

Fungsionalitas merupakan faktor paling utama yang harus dimiliki sebuah karya desain. Bagaimanapun wujud sebuah karya desain ia harus memenuhi fungsi utamanya. Apabila sebuah karya desain tidak dapat memenuhi fungsi utamanya maka karya desain tersebut dianggap gagal. Louis Sullivan, seorang arsitek kenamaan, pernah melontarkan pernyataan tentang perwujudan bentuk pada sebuah karya desain, dengan mengatakan "Form ever follow function. That is the law" (Bentuk selalu megikuti fungsi. Itulah hukumnya). Pernyataan ini sangat tegas menekankan perlunya proses desain pengedepankan ketercapaian aspek fungsionalitas. Pewujudan bentuk dipandangnya sebagai akibat dari pemenuhan fungsi.

b. Aspek Estetik

'Estetik' adalah suatu istilah yang sering didentikkan dengan 'keindahan'. The Liang Gie (1976: 56) misalnya, mengemukakan bahwa nilai-nilai estetik dapat dipahami sebagai nilai yang berhubungan dengan segala sesuatu yang tercakup dalam pengertian keindahan. Keindahan itu sendiri oleh banyak ahli diartikan dalam sudut pandang yang relatif berbeda-beda, antara lain dikemukakan oleh Herbert Read bahwa, keindahan adalah "kesatuan dari hubungan-hubungan bentuk di antara penerapan-penerapan inderawi kita". John Ruskin juga menandaskan bawa, "suatu benda material yang dapat memberi kita kesenangan dalam pemikiran sederhana mengenai kualitasnya yang tampak keluar tanpa sesuatu penggunaan kecerdasan secara langsung dan pasti, saya menamakan satu cara atau suatu taraf yang indah" (Gie, 1996: 15).

Meski telah banyak ahli yang berusaha memberikan batasan tetang konsep estetik dengan nuansa yang relatif berbeda-beda, namun secara umum penekanan perlunya petimbangan estetis dalam sebuah karya berada pada satu kerangka tujuan, yaitu untuk pemenuhan kenikmatan rasa indah.

Ada beberapa unsur yang lazim membentuk kenikmatan visual, biasa disebut sebagai aspek estetik desain, yakni komposisi (compotition), proporsi (proportion), keseimbangan (balance), penekanan (emphasis), irama (rhythm), dan kesatuan (unity). Komposisi adalah pengaturan unsur-unsur desain yang mempertimbangkan aspek-aspek yang telah disebutkan. Proporsi adalah perbandingan antara bagian satu dengan bagian lainnya. Perbandingan ini menyangkut besar-kecil, luas-sempit, panjang-pendek, dan tinggi-rendah. Keseimbangan adalah berkenaan dengan kualitas bobot atau kesan berat ringannya suatu karya. Keseimbangan dapat dibuat secara formal atau dengan istilah yang lazim disebut setangkep (jawa) atau simetris. Keseimbangan dapat di buat pula secara informal atau asimetris dan keseimbangan radial atau memancar. Penekanan biasa pula disebut prinsip dominasi atau, pusat perhatian, atau klimak, yaitu pemberian pusat perhatian atau daya tarik kuat pada bagaian tertentu suatu karya desain. Hal itu dapat dilakukan dengan cara pengaturan posisi, perbedaan ukuran, perbedaan warna, atau unsur lain, 
dan pengaturan arah unsur-unsur. Irama yaitu kesan gerak atau pengulangan yang teratur. Hal itu dapat dilakukan terhadap unsur garis, warna, bentuk, dan susunan. Kesatuan atau keselasan yaitu kesesuaian atau keserasian semua unsur yang tampil pada sebuah karya. Ketercapaian prinsip ini sangat didukung oleh terpenuhinya prinsip keseimbangan, irama, penekanan, dan proporsi.

Selain kedua prinsip utama di atas (fungsi dan estetika), pada desain kreatif perlu pula pertimbangan aspek eknomi, aspek sosial-budaya, aspek lingkungan, dan aspek teknologi. Aspek ekonomi berkaitan dengan pertimbangan hemat biaya, baik pengerjaan maupun perawatan. Aspek sosial-budaya berkaitan dengan pertimbangan kesesuaian desain dengan karakter soaial-budaya pengguna dan lingkungannya. Aspek lingkungan berkaitan dengan daya dukung terhadap keberlangsungan alam, tidak merusak lingkungan, dan memungkinkan adanya daur ulang. Aspek teknologi berkaitan dengan pertimbangan ketersediaan teknologi pendukung, baik dalam hal penyediaan bahan maupun pengerjaan.

\section{B. Ruang Dalam (Interior) dan Unsur Pembentuknya}

a. Pengertian Ruang Dalam (Interior)

Banyak pengertian ruang yang dapat kita jumpai. Menurut kamus, ruang ialah (1) sela-sela antara dua (deret) atau empat tiang; (2) rongga yang terbatas atau yang lingkung oleh bidang; (3) rongga yang tidak terbatas atau tempat segala yang ada. Menurut Plato, ruang adalah sesuatu yang terlihat dan teraba, menjadi teraba karena memiliki karakter yang jelas berbeda dengan semua unsur lainnya. Menurut Leibniz, "ruang adalah sesuatu yang diakibatkan oleh hubungan antar obyek". Menurut Kant, "ruang adalah konsep sistematis yang sebenarnya diciptakan dalam pikiran kita untuk menjelaskan persepsi yang diterima akibat sensasi panca indera dengan hal-hal lain yang berhubungan dengan kita sebagai subyek" (Astudio, 2009). Menurut Lao Tzu, "ruang adalah 'kekosongan' yang ada di sekitar kita maupun di sekitar objek atau benda". Menurut Taufan Hidjaz (2004: 58), "ruang adalah lingkungan spasial terbatas yang melingkupi individu sedemikian rupa, sehingga memungkinkan interaksi antara individu tersebut dengan ruang itu". Menurut logika Samoke, "ruang adalah dimensi suasana yang batasannya bisa kita jangkau. Sesuatu yang tertangkap, melalui indera kita. Ruang adalah batas tangkapan indera kita, baik dalam ukuran besar maupun dalam ukuran kecil" (astudio, 2009).

Berdasarkan beberapa pengertian di atas dapat ditarik pengertian umum tentang ruang yang dijadikan pijakan dalam penelitian ini ialah sela atau rongga yang menunjukkan keluasan atau dimensi suasana di sekitar kita maupun di sekitar objek atau benda, yang batasannya bisa dijangkau. Pengertian ini bermakna bahwa ruang dapat dibedakan antara ruang yang dilingkupi oleh bidang-bidang pembatas dan ruang di luar bidang pembatas. Berangkat dari pengertian ini, dapat dikemukakan pengertian ruang dalam (interior) yakni spasial yang menunjukkan keluasan di dalam suatu bangunan. Sejalan dengan itu, dalam Kamus Besar BI disebutkan bahwa, interior diartikan bagian dalam dari suatu gedung serta tatanan perabot yang ada di dalamnya.

Ruang interior menurut Taufan Hidjaz (2004: 53) dikenali dengan menelaah elemen-elemen yang terkandung di dalamnya. Ruang selalu melingkupi keberadaan manusia dan melalui volume ruanglah manusia bergerak, melihat bentuk-bentuk benda, mendengar suarasuara, merasakan angin bertiup dan mencium bau semerbak. Pada ruang, bentuk visual, kualitas cahaya, dimensi dan 
Agussalim Djirong \& Sukarman B, Analisis Daya Dukung Ruang Kuliah Dan Ruang Laboratorium/Studio Program Studi Pendidikan Seni Rupa Pada Fakultas Seni Dan Desain Universitas Negeri Makassar Ditinjau Dari

skala bergantung seluruhnya pada batasbatas yang telah ditentukan oleh unsurunsur bentuk. Jika ruang telah ditetapkan, dilingkupi, dan diorganisir oleh unsurunsur bentuk, maka ketika iutulah interior menjadi sebuah realitas.

\section{b. Unsur-Unsur Pembentuk Ruang Dalam}

Sebuah ruang diidentifikasi sebagai ruang dalam (interior) karena adanya elemen-elemen yang membentuknya. Secara umum, ada tiga elemen pembentuk ruang dalam, yaitu:

\section{Bidang alas/lantai (the base plane)}

Lantai merupakan unsur penting suatu ruang. Lantai merupakan satu bidang yang memiliki unsur bentuk, warna, pola, dan tekstur. Unsur-unsur bidang lantai itu ikut berperan dalam menentukan batas-batas ruang di samping berfungsi sebagai dasar yang secara visual menimbulkan kesan tersendiri. Lantai merupakan salah satu bidang ruang yang sangat mendukung aktivitas manusia dalam suatu bangunan. Oleh karena itu, secara struktural lantai harus kuat dan awet. Tekstur dan kepadatan materialnya akan mempengaruhi cara orang berjalan di atasnya permukaannya.

2. Bidang dinding/pembatas (the vertical space devider)

Dinding sebagai satu elemen ruang merupakan bidang yang dapat menyatu atau terpisah dengan bidang lantai. Bidang dinding bisa berfungsi sebagai latar belakang yang netral bagi unsur-unsur lain yang ada di dalam suatu ruang atau sebagai unsur visual yang aktif pada suatu ruang. Bidang dinding juga dapat transparan seperti halnya sebuah sumber cahaya atau suatu pemandangan.

\section{Bidang langit-langit/atap (the overhead} plane)

Atap adalah unsur pelindung utama pada suatu bangunan, terutama melindungi bagian dalam dari pengaruh iklim. Secara visual, bidang atap merupakan 'topi' suatu bangunan, yang memiliki pengaruh kuat terhadap bentuk bangunan dan pembayangan.

Selain ketiga unsur utama pembentuk ruang di atas, ada pula beberapa faktor lain yang turut mempengaruhi terbentuknya ruang, yakni dimensi, wujud, konfigurasi, permukaan, sisi-sisi, dan bukaan. Faktor-faktor ini disebut penentu keterangkuman ruang.

\section{Aspek Penentu Suasana Ruang}

Suasana ruang menurut Taufan Hidjaz (2004: 59) dapat dibedakan menjadi tiga aspek, yaitu aspek lingkungan fisik, aspek psikologik, dan aspek sosial. Setiap aspek mengandung kelompok-kelompok stimuli yang khas. Setiap kelompok stimuli yang khas membentuk variabel. Aspek lingkungan visik mengandung variabel-variabel kondisi suhu udara, atmosfir, nutrisi, pencahayaan, tingkat kebisingan, objek lingkungan, dan spasial. Aspek psikologik menunjuk pada variabelvaribel keleluasaan pribadi (privacy), ruang seputar badan, kontak mata, ketertutupan ruang, penataan perabotan, kedekatan atau ketertarikan dengan orang lain, kepadatan pemakaian ruang, dan lingkungan prilaku. Aspek sosial dapat diwakili oleh 'resourcesstimuli' yang diungkapkan menurut variabelvariabel cinta, status, pelayanan, informasi, barang, uang, dan semuanya itu menjadi "hal yang dipetukarkan" dalam interaksi sosial. Komposisi dari semua variabel, masingmasing dengan kualitas tertentu menghasilkan 'resultante' yang disebut sebagai "suasana ruang".

Sejalan dengan pendapat di atas, Elly Cornelies dkk. mengemukakan beberapa faktor yang pada bagian terdahulu disebut sebagai penentu keterangkuman ruang, merupakan aspek yang sangat menentukan suasana ruang, yakni:

\section{Dimensi}


Dimensi adalah ukuran panjang, lebar, dan tinggi. Dimensi mencakup skala dan proporsi yang ditentukan berdasarkan perbandingan dengan ukuran relatifnya dengan bentukbentuk lain di sekelilingnya. Unsur ini dapat diatur sedemikian rupa untuk menghasilkan efek-efek tertentu misalnya efek wajar, megah, mencekam, dsb.

\section{Wujud}

Wujud adalah ciri-ciri pokok yang menunjukkan bentuk. Bentuk adalah "objekobjek dalam persespsi kita memiliki wujud/ujud (shape), (Abecromie, 1984: 37). Sementara itu, (Ching, 1979) mengatakan bahwa, bentuk dapat dikenali karena ia memiliki ciri visual yakni wujud, dimensi, warna, tekstur, posisi, orientasi, dan inersia visual. Konfigurasi tertentu pada permukaanpermukaan dan sisi suatu bentuk akan menghasilkan wujud yang tertentu pula. Bentuk yang terjadi dari konfigurasi memberikan pengaruh secara fisik maupun psikologis kepada pengamat dan pengguna ruang.

\section{Permukaan dan Sisi}

Permukaan dan sisi akan menentukan kualitas suatu ruang melalui pengaturan warna, tekstur, dan pola. Pemberian warna, tekstur, dan pola tertentu pada permukaanpermukaan bidang pembentuk ruang (lantai, dinding, dan langit-langit) akan memberikan kesan tertentu pula pada ruang bersangkutan. Peran Warna pada permukaan atau sisi ruang dapat dirancang untuk menstimuli (memberi ransangan), memfokuskan atau mengalihkan perhatian, memberi kesan luas atau sempit, dan menciptakan kesan tertentu (seperti: hangat, dingin, tenang, riang dsb.).

\section{Bukaan}

Bukaan adalah faktor yang berkaitan dengan tingkat ketertutupan, cahaya, dan pandangan. Ukuran, bentuk, dan letak bukaan atau void sangat berpengaruh terhadap tingkat kenyamanan penggunaan ruang. Suasana yang ditimbulkan oleh pengaturan bukaan akan memberikan efek fisik maupun psikologis.
Oleh karena semua aspek yang disebutkan di atas sangat berpengaruh terhadap terbentuknya suasana ruang, maka dalam melakukan penataan ruang dalam (interior), pengaturan aspek-aspek tersebut perlu mendapat perhatian dan dielaborasi dengan matang.

\section{Hubungan Suasana Ruang dengan Kegiatan Manusia}

Taufan Hidjaz menyatakan bahwa, suasana ruang merupakan atribut dari lingkungan spasial terbatas berupa dampak samar-samar (diffused) kondisi ruang secara keseluruhan yang berpengaruh terhadap proses metabolik, persepsi sensorik, dan aestetik response pada anusia dalam ruang itu. Suasana ruang adalah suasana yang dipancarkan oleh ruang sebagai lingkungan buatan manusia, merupakan kualitas yang dapat diintervensi dan ditingkatkan sampai batas dan kebutuhan tertentu dan untuk membentuk dampak yang tertentu pula terhadap kegiatan manusia di dalamnya. Perubahan dalam suasana ruang dimungkinkan dengan cara menangani dan mengendalikan komponen-komponen pembentuknya sedemikian rupa, sehingga resultante-nya dapat menghasilkan kondisi utuh yang diperlukan guna menciptakan suasana yang dikehendaki.

Suasana ruang merupakan masukan (input) pada manusia, yang kemudian dikonversi menjadi luaran (output) berupa dingkah laku (kegiatan). Sebaliknya, kegiatan manusia itu sendiri dapat mempengaruhi suasana ruang.

Proses interaksi antara manusia dengan suasana ruang menghasilkan constrain, menurut aspek organik, psikologik, dan sosial. Intervensi terhadap proses interaksi antara manusia dengan ruang antara lain bertujuan untuk menciptakan suasana ruang yang sesuai dengan derajat kondisi peradaban dan budaya yang diinginkan. Penciptaan suasana ruang menurut citra dan konsep tertentu mempunyai maksud untuk mempengaruhi kegiatan yang 
Agussalim Djirong \& Sukarman B, Analisis Daya Dukung Ruang Kuliah Dan Ruang Laboratorium/Studio Program Studi Pendidikan Seni Rupa Pada Fakultas Seni Dan Desain Universitas Negeri Makassar Ditinjau Dari

dilakukan manusia yang bersangkutan di dalam ruang tersebut.

\section{METODE PENELITIAN}

Berdasarkan judul yang diajukan, ditetapkan variabel yang akan menjadi fokus kajian dalam peneltian ini, yakni keefektifan tata ruang ditijnau dari aspek desain, yang secara operasional didefinisikan sebagai "daya dukung unsur pembentuk ruang dan seluruh komponen pendukungnya dalam penciptaan suana nyamanan dan ketepatgunaan ruang dalam (interior) berdasarkan kesesuaian dengan prinsip-prinsip desain dan tata ruang yang lazim digunakan.

Sasaran utama penelitian ini adalah ruang kuliah sebanyak 7 ruangan dan ruang lab/studio sebanyak 6 ruangan pada program studi Pendidikan Seni Rupa Fakultas Seni dan Desain Universitas Negeri Makassar.

Data yang dibutuhkan dalam penelitian ini berupa data visual beserta catatan yang mendeskripsikan keadaan setiap ruang yang diteliti. Data itu diperoleh dengan cara melakukan survei secara langsung pada setiap ruang dan mencatat kondisi riil tata ruang tersebut dan mendokumentasikannya melalui rekaman kamera foto dan atau kamera video.

Data yang telah diperoleh diolah dengan cara mengelompokkan data visual dan catatan survei menurut ruangnya. Selanjutnya, data yang telah diolah kemudian dianalisis secara kualitatif dengan melakukan komparasi antara kondisi riil tata ruang dengan prinsip desain tata ruang dalam (interior) yang lazim digunakan.

\section{PEMBAHASAN}

Pembahasan hasil penelitian ini dibedakan atas pembahasan ruang kuliah dan pembahasan ruang laboratorium/studio, yakni sebagai berikut:

\section{Ruang Kuliah}

Ruang kuliah yang dijadikan sasaran atau yang terdata dalam penelitian ini sebanyak enam buah. Pembahasan terhadap keenam ruangan tersebut dilakukan untuk melihat kefektifannya dengan menganalisis daya dukung unsur-unsur pembentuk suasananya, yang meliputi dimensi, wujud konfigurasi, permukaan, dan bukaan.

a) Dimensi

Dimensi interior berkaitan dengan skala atau proporsi yang dapat dinyatakan keefektifannya dengan membandingkan panjang, lebar, dan tinggi ruangan, serta membandingkannya dengan jumlah penggunanya. Menurut standar pendidikan, untuk seorang mahasiswa membutuhkan ruang kuliah seluas $2 \mathrm{~m}^{2}$. Melihat proposi ketujuh ruang kuliah yang memiliki tinggi 4,5m dengan lebar dan panjang bervariasi dapat dikatakan cukup baik. Pandangan baik ini terutama disasarkan pada ketinggian langit-langit $4,5 \mathrm{~m}$ yang menciptakan jarak dengan lantai cukup longgar. Demikian pula dengan proporsi yang didasarkan atas perbandingan dengan jumlah penggunanya dapat dikatakan baik oleh karena jumlah pengguna disesuaikan dengan luas ruangan. Dalam hal dimensi, ruang kuliah secara umum dapat dikatakan efektif.

b) Wujud Konfigurasi

Wujud konfigurasi berkaitan dengan bentuk dan tata prabot. Semua ruang kuliah pada program studi Pendidikan Seni Rupa memiliki bentuk standar, yakni persegi, dengan kata lain tidak ada variasi bentuk. Bentuk seperti ini memberikan efek luas pada ruangan serta memberi kesan formal. Dalam hal ini, dapat dikatakan wujud konfigurasi ruangan kuliah secara umum mendukung suasana ruang formal. Berbeda halnya dengan tata perabot, terdapat perbedaan pada beberapa ruang kuliah, namun pada umumnya perabot yang ada hanya kursi kuliah, meja dan kursi dosen, whiteboard, dan LCD di sebagian ruangan. Susunan kursi pada ruang kuliah 1 membentuk kelas yang memanjang ke samping karena menghadapi lebar ruangan. Meskipun kelas memanjang ke samping, 
tata perabot ruang kelas ini masih cukup mendukung terwujudnya suasana nyaman dalam dan formal meskipun kelas seperti itu tidak umum. Sedikit berbeda dengan ruang kelas 2, susunan kursi membentuk kelas memanjang ke belakang. Susunan semacam ini umum digunakan, namun hadapan kelas pada sisi ruangan yang terdapat pintu kurang mendukung kefektifan pembelajaran, terutama jika pintu terbuka. Posisi whiteboard berdekatan dengan pintu dapat menyebabkan proses pembelajaran terganggu karena suasana di pintu dapat dengan mudah mengalihkan perhatian mahasiswa. Dari sudut estetika, penempatan whiteboard berdekatan dengan pintu menimbulkan kesan tidak seimbang. Hal yang sama terjadi pada ruang kuliah 3 , 5, dan 6. Tataan perabot yang lebih mendukung terwujudnya suasana pembelajaran yang efektif yakni ruang kuliah 4. Sususnan kursi pada ruangan ini menciptakan kelas memanjang ke belakang. Whiteboard terpasang di dinding hadapan kelas dengan tidak ada objek atau benda lain di sekitarnya yang dapat mengalihkan perhatian. Meja dan kursi dosen serta fodium ditempatkan dipojok ruangan hadapan kelas.

c) Permukaan/Sisi

Permukaan atau sisi berkaitan dengan warna, tekstur, dan pola. Warna ruang kuliah secara umum terdiri atas warna putih, putih keabu-abuan, jingga, dan coklat tua. Kombinasi beberapa warna pada ruang kuliah menciptakan kesan ramai. Pada ruangan 1,2 , dan 3 , warna dinding bahkan divariasi dengan pola yang berbeda-beda antara setiap ruangan menambah kesan ramai dan semaraknya ruangan. Ditinjau dari aspek ini, warna ruang kuliah seperti itu kurang sesuai dengan karakter ruangan yang seharusnya berkesan tenang dan serius. Tekstur juga demikian, meskipun secara umum bertekstur halus, namun kombinasi dan variasi warna pada beberapa ruangan seperti ruangan 1, 2, dan 3 memeberi kesan tekstur kasar. Tekstur seperti itu memberi kesan ramai dan nonformal. Pada umumnya ruang kuliah menggunakan pola persegi baik bentuk maupun warna, namun ada tiga ruangan di antaranya yang menggunakan pola garis lengkung dan lingkaran pada variasi warnanya. Hal itu menguatkan terciptanya kesan ramai dan nonformal.

d) Bukaan

Bukaan pada interior berkenaan dengan tingkat ketertutupan, cahaya, dan pandangan. Boleh dikatakan semua ruangan memiliki tingkat ketertutupan tinggi karena di keempat sisinya dibatasi dinding. Beberapa di antara ruang kuliah memiliki bukaan memadai sebagai sumber cahaya dan penghawaan, dan beberapa juga di antaranya kurang memiliki bukaan untuk pencahayaan dan penghawaan sehingga intensitas cahaya dan hawa yang masuk sangat rendah. Pada ruangan yang kurang memiliki bukaan pencahayaan dan penghawaan membutuhkan bantuan cahaya lampu untuk memperjelas pandangan, serta AC untuk menyejukkan ruangan. Ruangan yang kurang memiliki bukaan menjadi kurang efisien dan pada saat tidak ada aliran listrik menjadi tidak efektif mendukung terciptanya suasana ruang yang nyaman untuk proses pembelajaran.

2. Ruang Laboratorium/Studio

Ruang laboratorium/studio yang dijadikan sasaran atau yang terdata dalam penelitian ini sebanyak empat buah. Seperti halnya pembahasan ruang kuliah, pembahasan terhadap keempat ruang laboratorium/studio tersebut dilakukan untuk melihat kefektifannya dengan menganalisis daya dukung unsur-unsur pembentuk suasananya, yang meliputi dimensi, wujud konfigurasi, permukaan, dan bukaan.

a) Dimensi 
Agussalim Djirong \& Sukarman B, Analisis Daya Dukung Ruang Kuliah Dan Ruang Laboratorium/Studio Program Studi Pendidikan Seni Rupa Pada Fakultas Seni Dan Desain Universitas Negeri Makassar Ditinjau Dari

Dimensi interior berkaitan dengan skala atau proporsi. Pada aspek ini, perbandingan panjang, lebar, dan tinggi ruangan laboratorium/studio dapat dikategorikan baik karena jarak langitlangit deng lantai cukup memberi efek luas. Lain halnya bila unsur proporsi dilihat berdasarkan perbandingan keluasan ruangan dengan kondisi prabot jumlah pengguna ruangan tersebut. Standar pendidikan menganggap ruang ideal laboratorium/studio untuk seorang mahasiswa adalah $9 \mathrm{~m}^{2}$. Berdasarkan standar ini, dengan rata-rata jumlah mahasiswa setiap kelas sebayak 30 orang, serta dengan menghitung kehadiran prabot dan benda-benda lainnya dalam ruangan dapat dikatakan bahwa ruang laboratorium/studio pada program studi Pendidikan Senirupa FSD UNM pada umumnya kurang proporsional. Dengan demikian, dapat pula dikatakan kurang efektif mendukung terciptanya suasana kerja/belajar di laboratorium/studio. Kondisi itu terutama tampak pada studio kayu, studio patung, dan studio grafis.

b) Wujud Konfigurasi

Wujud konfigurasi berkaitan dengan bentuk dan tata prabot. Semua ruang laboratorium/studio pada program studi Pendidikan Seni Rupa memiliki bentuk standar, yakni persegi, dengan kata lain tidak ada variasi bentuk. Bentuk seperti ini memberikan efek luas pada ruangan serta memberi kesan formal. Dalam hal ini, dapat dikatakan wujud konfigurasi laboratorium/studio secara umum mendukung suasana ruang formal. Akan tetapi, wujud konfigurasi dari segi tata prabot kurang menunjukkan yang mendukung terciptanya suasana kerja/belajar yang nyaman, terutama tampak pada studio kayu dan patung.
Kedua studio ini tampak sesak sehingga membatasi ruang gerak mahasiswa saat bekerja. Kondisi tata ruang yang sangat semraut tampak pada studio kayu. Pengaturan yang semraut terkesan seperti gudang tidak mendukung terciptanya suasana ruang yang nyaman untuk bekerja.

c) Permukaan/Sisi

Permukaan atau sisi berkaitan dengan warna, tekstur, dan pola. Warna ruang laboratorium/studio secara umum terdiri atas warna putih, putih keabuabuan, dan coklat tua. Dominasi putih dalam kombinasi warna tersebut tampak mendukung terciptanya kesan formal. Demikian halnya permukaan dinding yang halus dan dicat polos sehingga menunjukkan tekstur halus yang berkesan formal pula. Keseluruhan bentuk maupun warna ruang laboratorium/studio menggunakan pola persegi. Pola demikian mengesankan keseriusan yang mendukung suasana formal.

d) Bukaan

Bukaan pada interior berkenaan dengan tingkat ketertutupan, cahaya, dan pandangan. Boleh dikatakan semua ruang laboratorium/studio memiliki tingkat ketertutupan tinggi karena di keempat sisinya dibatasi dinding. Namun demikian, pada umumnya ruang laboratorium/ studio memiliki bukaan memadai sebagai sumber cahaya dan penghawaan. Bukaan berupa fentilasi dan jendela dimaksimalkan pada ruang laboratorium/studio untuk mendapatkan cahaya dan hawa alami yang maksimal dari luar ruangan. Bukaan maksimal menyebabkan ruang laboratorium/ studio tidak mengharuskan penggunaan lampu di siang hari karena pandangan cukup jelas, serta tidak membutuhkan penggunaan penyejuk ruangan karena 
sirkulasi udara cukup baik. Kondisi bukaan seperti itu dapat dikatakan efektif mendukung terciptanya suasana belajar yang nyaman.

\section{SIMPULAN}

Berangkat dari hasil pembahasan yang telah diuraikan sebelumnya, maka hasil penelitian ini dapat disimpulkan sebagai berikut:

1. Ruang kuliah dan ruang laboratorium/studio ditinjau dari aspek dimensi yang mencakup skala/proporsi, khususnya menyangkut perbandingan ukuran panjang, lebar, dan tinggi, tergolong baik. Namun, bila diperbandingkan antara daya tampung dengan kondisi prabot dan jumlah rata-rata mahasiswa setiap kelas, khususnya ruang laboratorium/studi, tergolong sempit sehingga kurang efektif mendukung terciptanya suasana belajar/kerja yang nyama di studio tersebut.

2. Ditinjau dari aspek wujud konfigurasi, khususnya mencakup bentuk, seluruh ruang kuliah dan ruang laboratorium/studio pada program studi Pendidikan Seni Rupa FSDUNM memiliki bentuk standar, yakni persegi, dengan kata lain tidak ada variasi bentuk. Dari aspek tata prabot, ruang kuliah mengunakan pola umum yakni kursi kuliah berjajar, ada yang membetuk kelas memanjang ke samping dan ada pula yang membentuk kelas memanjang ke belakang. Beberapa ruang kuliah menempatkan whiteboard berdampingan dengan pintu pada satu sisi sehingga tataan itu kurang efektif mendukung terciptanya suana belajar yang baik. Tata parabot di ruang studio pada umumnya terkesan sesak dan semraut, bahkan ada terkesan seperti gudang sehingga kondisi itu tidak efektif mendukung terwujudnya suasana kerja/belajar yang nyaman di studio tersebut.

3. Ruang kuliah program studi Pendidikan Seni Rupa FSD-UNM pada umumnya mengkombinasikan warna putih, putih keabuabuan, jingga, dan coklat tua. Permukaan/sisi seluruh ruangan bertekstur halus dan kasar. Halus karena permukaan sisi dilicinkan, sedangkan kesan kasar tampak pada les-les penutup pertemuan lembaran platfon, garisgaris pertemuan tegel (nat), dan permainan warna pada dinding dan sebagian langit-langit. Permukaan pada umumnya menggunakan pola persegi, kecuali variasi warna pada dinding beberapa ruangan menggunakan pola lengkung dan lingkaran. Penggunaan warna jingga dengan bentuk yang bervariasi pada ruangan kuliah mengesan ruang nonformal segingga kurang efektif mendungkung terwujudnya citra estetik yang berkesan serius/formal. Berbeda dengan studio, baik warna, tekstur, maupun pola permukaan/sisi secara umum mendukung terwujudnya citra estetik formal.

4. Bukaan pada interior berkenaan dengan tingkat ketertutupan, cahaya, dan pandangan. Boleh dikatakan semua ruang kuliah dan ruang laboratorium/studio memiliki tingkat ketertutupan tinggi karena keempat sisi setiap dibatasi oleh dinding sehingga pandangan ketika memasuki ruangan-ruangan tersebut langsung dibatasi oleh dinding. Intensitas cahaya dan hawa alami pada ruang kuliah berAC sangat rendah sehingga sangat bergantung pada berfungsinya AC dan sinar lampu. Dengan demikian, ruangan tersebut kurang efisien dan pada saat AC dan lampu tidak berfungsi maka tata cahaya dan penghawaan ruangan tersebut sangat tidak efektif mendukung terciptanya suasana belajar yang nyaman. Namun, pada ruangan yang tidak ber$\mathrm{AC}$, intensitas cahaya dan hawa alami yang masuk cukup memadai dan mendukung terciptanya suasana belajar yang nyaman pada ruangan tersebut, meskipun cuaca di luar ruangan dalam keadaan berawan atau mendung. Demikian pula halnya ruang laboratorium/studio, seluruhnya dirancang tidak menggunakan AC dengan memaksimalkan pemanfaatan cahaya dan hawa alami. Hanya saja karena kesesatan perabot pada ruang studio tertentu mengakibatkan berkurangnya cahaya alami yang masuk dan juga mengurangi kesejukan ruangan. Namun, secara umum sistem bukaan ruang laboratorium/studio masih mendukung 
Agussalim Djirong \& Sukarman B, Analisis Daya Dukung Ruang Kuliah Dan Ruang Laboratorium/Studio Program Studi Pendidikan Seni Rupa Pada Fakultas Seni Dan Desain Universitas Negeri Makassar Ditinjau Dari

terciptanya suasana belajar/kerja di studio tersebut, walaupun dalam kondisi tertentu membutuhkan bantuan penyejuk seperti kipas angin.

\section{Saran}

Berdasarkan kesimpulan di atas, disarankan beberapa hal sebagai berikut:

1. Untuk meningkatkan efektifitas unsur-unsur pendukung ruang terhadap penciptaan suasana pembelajaran yang nyaman pada ruangan kuliah perlu meredesain interior ruangan-ruangan tersebut, terutama pada:

- Sistem pencahayaan dan penghawaan, hendaknya mengantisipasi ketidakberfungsian penyejuk dan lampu penerang dengan memaksimalkan pemanfaatan cahaya dan hawa alami.

- Pewarnaan, hendaknya mendukung terciptanya kesan formal, sejuk, teratur, serta sesuai dengan karakteristik penggunanya.

- Wujud konfigurasi, khususnya tata prabot, hendaknya mewujudkan bentuk kelas yang dapat mengurangi efek pengganngu dalam pelaksanaan kegiatan pembelajaran.

2. Untuk meningkatkan efektifitas unsur-unsur pendukung ruang terhadap penciptaan suasana kerja dan pembelajaran yang nyaman pada ruangan laboratorium/ studio perlu meredesain interior ruangan-ruangan tersebut, terutama pada aspek tata prabot dengan:

- mengeleminir barang-barang yang tidak diperlukan berkaitan dengan kegiatan yang harus dikerjakan pada studio-studio tersebut.

- Mengatur kembali prabot dan peralatan yang seharusnya ada pada setiap studio dengan memperhitungkan keluasaan gerak (sirkulasi) pengguna, sirkulasi udara, intesitas cahaya yang akan masuk, dan keindahan pandangan.

\section{DAFTAR RUJUKAN}

Abercrombie, Stanley, 1984: Architecture as Art An Esthetic Analisys, Van Nostrand Reinhold, New York.

Bevlin, Majorie Elliot, 1980: Design Through Discovery, Holt, Rinegart and Winston, New York Chichago San Francisco Atlanta Dallas Montreal Toronto London Sydney.

Ching, Francis DK., 1979: Arsitektur: Bentuk, Ruang, dan Susunannya, Erlangga, Jakarta.

Eko Nurmianto, 1996: Ergonomi (Konsep Dasar dan Aplikasinya), PT. Guna Widya, Jakarta.

Mangun Wijaya, Y.B, 1995: Wastu Citra, PT. Gramedia Pustaka Utama, Jakarta.

Massey, Anne, 1990: Interior Design of the 20th Century, Thames and Hudson, London.

Tanpa Nama, 1999: Teori Arsitektur, Buku Ajar Arsitektur dalam Penataran Dosen PTS dalam Rangka Perluasan Wawasan dan Penguasaan Bidang Arsitektur, Jakarta.

Taufan Hidjaz, 2004: Terbentuknya Citra dalam Konteks Suasana Ruang dalam Jurnal Dimensi Interior, Jurusan Desain Interior Fakultas Seni dan Desain Universitas Keristen Petra, Surabaya.

Wong, Wucius, 1986: Beberapa Asas Merancang Trimatra, Penerbit ITB Bandung.

http://astudioarchitect.com/2009/08/diskusitentang-ruang-dalam-ruang-angan.html. 